\title{
Assessment of thermodynamic cycle of internal combustion engine in terms of rightsizing
}

The modification of the downsizing trend of internal combustion engines towards rightsizing is a new challenge for constructors. The change in the displacement volume of internal combustion engines accompanying the rightsizing idea may in fact mean a reduction or increase of the defining swept volume change factors and thus may affect the change in the operating characteristics as a result of changes in combustion process parameters - a research problem described in this publication. Incidents of changes in the displacement volume were considered along with the change of the compression space and at the change of the geometric degree of compression. The new form of the mathematical dependence describing the efficiency of the thermodynamic cycle makes it possible to evaluate the operation indicators of the internal combustion engine along with the implementation of the rightsizing idea. The work demonstrated the invariance of cycle efficiency with different forms of rightsizing.

Key words: internal combustion engine, thermodynamic cycle, rightsizing

\section{Introduction - defining the research problem}

Continuous work on improving the efficiency of internal combustion engines results in a variety of development trends. One of them is downsizing, lasting for over ten years, which has recently been modified in the direction of not reducing the displacement volume, but also the proper selection of its size in order to ensure reduction of fuel consumption and carbon dioxide emission to the atmosphere while simultaneously satisfying users' comfort of operation as, for example, the possibility of transporting a certain size of cargo, constituting a sustainable development of means of transport. The new development trend is called rightsizing.

Each change in the geometrical volume of the combustion chamber is accompanied by a change in the conversion of energy contained in the fuel, which in its assumption should burn completely. The change in the swept volume of internal combustion engines accompanying the rightsizing idea may in fact mean a reduction or increase in the coefficients defining the displacement volume and thus may affect the change in the operating characteristics as a result of changes in the combustion process parameters.

The assessment of the impact of changes in the rightsizing index on the efficiency of the thermodynamic cycle of an internal combustion engine is a research problem described in this publication.

\section{Rightsizing vs. downsizing}

Constructive activities in the field of development works with the use of the rightsizing idea are associated primarily with the increase in unit power as one of the significant engine performance indicators. So these are actions that coincide with earlier ones in the field of downsizing.

In order to preserve or even increase the unit power of the engine, it is necessary to support geometric changes in the displacement volume with systems, among which the most important place is: boosting, direct fuel injection and variable valve timing $[6,10-12]$.

The boosting of the internal combustion engine, which aims to increase the filling factor, has a different constructional and functional form, the most common of which is turbocharging using the energy of exhaust gases. It can be realized using a single turbo compressor system with fixed operation parameters or with variable settings of the turbine blades. Such systems can be one or two-stage, with or without cooling, etc. Boosting is the simplest system to support structural changes of the displacement volume, both in terms of preventing power losses and creating conditions conducive to burning poor mixtures that occur both in downsizing and rightsizing.

The second of the support systems - direct fuel injection is a system that guarantees the correct atomization of fuel droplets, which together with the possibility of several times their injection during a single cycle ensures full evaporation and combustion. The use of direct injection fits well into the operation of an engine with a reduced displacement volume (downsizing) because it directly replenishes the power losses resulting from changes in geometry. In the case of an increase in the displacement volume (possible rightsizing version), direct fuel injection ensures combustion of poor mixtures.

In turn, the variable valve timing system is characterized by a large range of different constructions, but their general working principle is to ensure that the angles and opening times of valve are adjusted to the current operational situation, i.e. rotational speed and engine load. Variable valve timing ensures proper filling of the combustion chamber, thus ensuring that the efficiency of the internal combustion engine is maintained and even increased and through functional boost and direct injection support conditions of stoichiometric combustion for both downsizing and rightsizing.

An engineering practice can show a number of examples of the development of downsizing ideas. These include engines mounted in Ford vehicles, where the $6.2 \mathrm{dm}^{3} \mathrm{~V} 8$ unit has undergone structural changes to $3.5 \mathrm{dm}^{3} \mathrm{~V} 6$, followed by $1.6 \mathrm{dm}^{3}$, to achieve a spectacular $0.999 \mathrm{dm}^{3}$ EcoBoost. In turn, the Volkswagen brand engines changing the displacement volume from $2.8 \mathrm{dm}^{3}$ or $2.0 \mathrm{dm}^{3}$ to $1.8 \mathrm{dm}^{3}$ and then to $1.4 \mathrm{dm}^{3}$, fulfilled the downsizing assumptions, reaching the 0.90 and 0.64 volume change ratios, to achieve 
1.07 when balanced (rightsizing) - when $1,4 \mathrm{dm}^{3}$ TSI changed to $1.5 \mathrm{dm}^{3}$ TSI.

The mentioned measure, both downsizing and rightsizing, is the degree (index) of changes, which is variously defined $[4,5,8,14,18,19]$, but generally informs about the change or the degree of residue after reducing or increasing the displacement volume. Unlike everybody, the authors defined the downsizing index $\left(\mathrm{W}_{\mathrm{d}}\right)$ based on the degree of changes in the components describing the cylindrical combustion space, which dominates the construction of internal combustion engines [19]. According to this definition, the downsizing index can be described as in formula (1).

$$
\begin{gathered}
W_{d}=1-A B^{2} \\
A=\frac{S_{d}}{S} \quad B=\frac{D_{d}}{D}
\end{gathered}
$$

In practical solutions, a mixed downsizing dominates, i.e. in which a simultaneous change in piston stroke is accompanied by a change in cylinder diameter. From the point of view of engine construction and manufacturing technology, single modifications are also possible. In [18, 19], various types of changes in the displacement volume of internal combustion engine were defined and described, taking them into mathematical and graphic forms.

By implementing the rightsizing idea, it is possible to obtain the same changes in the $\mathrm{W}_{\mathrm{d}}$ index at various changes in the value of stroke and diameter, which results from the difference in the values of the coefficients A and B (see Eq.( 1)) - Fig.1.

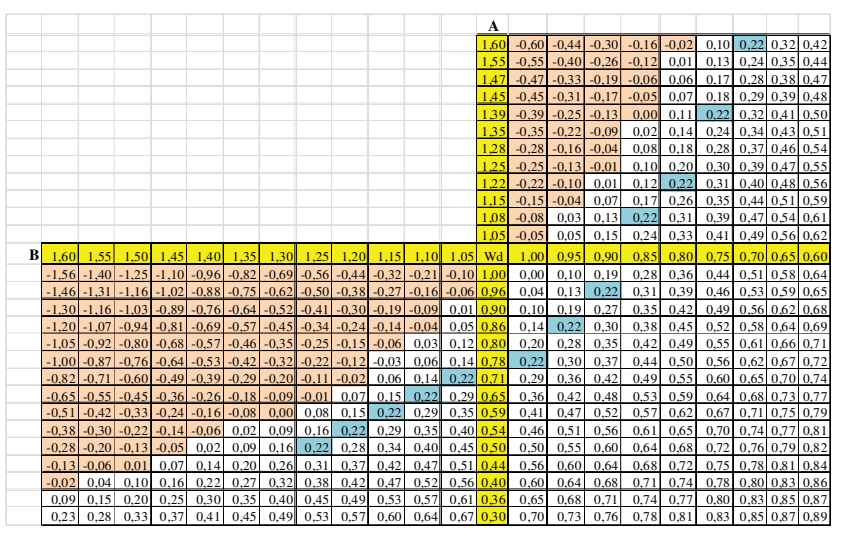

Fig. 1. Matrix of downsizing index $W_{d}$ with coordinates marked (coefficients $A$ and $B$ ) with the same values $W_{d}=0.22$

The changes in the $\mathrm{W}_{\mathrm{d}}$ included in the matrix in Fig. 1. indicate the possibility of any choice of changes in the A and B coefficients shaping the geometry of the combustion chamber. Positive values show decrease in downsizing volume and negative values declare its increase (upsizing). In this way it is possible for multiple actions to fulfill the idea of mixing according to the mixed rule i.e. with simultaneous change of $\mathrm{A}$ and $\mathrm{B}$. The values described in the matrix also indicate changes in the stroke volume realized by reducing one of the coefficients with the simultaneous increase of the second. For an exemplary change of $\mathrm{W}_{\mathrm{d}}=$ 0.22 (change in engine volume from 1.8 to $1.4 \mathrm{dm}^{3}$ ), many variants are possible, including changes in coefficients: A from 0.50 to 1.60 and B from 0.70 to 1.25 - Table 1 .
Table 1. The matrix of changes of the coefficients A and B for the down-

\begin{tabular}{|c|c|c|c|c|c|c|}
\hline No & Coeffi & nt A & Coef & ient $B$ & & \\
\hline & value & form & value & form & & Кетाпо \\
\hline 1. & 1.60 & \multirow{4}{*}{ 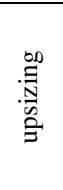 } & 0.70 & \multirow{6}{*}{ 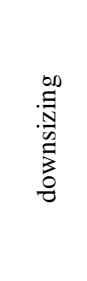 } & 0.44 & \\
\hline 2. & 1.39 & & 0.75 & & 0.54 & \\
\hline 3. & 1.22 & & 0.80 & & 0.66 & \\
\hline 4. & 1.08 & & 0.85 & & 0.79 & \multirow{4}{*}{ 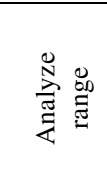 } \\
\hline 5. & 0.96 & \multirow{8}{*}{ 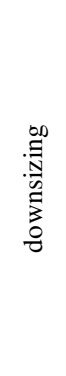 } & 0.90 & & 0.94 & \\
\hline 6. & 0.86 & & 0.95 & & 1.10 & \\
\hline 7. & 0.78 & & 1.00 & neutral & 1.28 & \\
\hline 8. & 0.71 & & 1.05 & \multirow{5}{*}{ 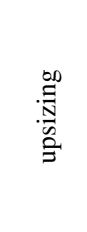 } & 1.48 & \\
\hline 9. & 0.65 & & 1.10 & & 1.69 & \\
\hline 10. & 0.59 & & 1.15 & & 1.95 & \\
\hline 11. & 0.54 & & 1.20 & & 2.22 & \\
\hline 12. & 0.50 & & 1.25 & & 2.50 & \\
\hline
\end{tabular}
sizing index $\mathrm{W}_{\mathrm{d}}=0.22$

Having knowledge about the design of the internal combustion engine in the area of the combustion chamber and crank system and commonly accepted geometrical relationships between the cylinder diameter and stroke [9, $13,15]$, as well as based on real relations of these parameters determined on the basis of engines from the Engine of the Year Competition $[19,20]$ it was possible to determine the range of variation of the ratio of cylinder diameter to piston stroke, which was evaluated from 1.28 to 0.79 . This authorizes to limit further considerations of the research problem to this range i.e. consideration of the influence of volume changes according to the rightsizing rules on cycle efficiency for cases: $\mathrm{A}=0.78-1.08$ and $\mathrm{B}=1.00-0.85-$ from Table 1.

The research problem put forward in the introduction, such as the variability of geometric changes demonstrated by the different values of the A and B coefficients, while maintaining the same swept volume change index, affect the operation of the internal combustion engine based on the identification of the generalized thermodynamic cycle.

\section{Efficiency of a generalized engine cycle in the aspect of rightsizing - research methodology}

In the combustion chamber of a reciprocating internal combustion engine, fuel mixed with air creates a working medium that undergoes thermodynamic changes related to, inter alia, changes in the volume of the combustion space. These changes are repetitive, although their size depends on the current engine operating conditions. The occurring transformations form the engine work cycle, described mathematically in various ways $[2,3,7,16,17]$. In the generalized form, corresponding to all known theories of internal combustion engines, the work cycle can be described by the efficiency $(\eta t)$ as per formula (2) and expressed graphically as in Fig. $2[1,2,16,17]$.

$$
\eta_{\mathrm{t}}=1-\frac{\frac{\lambda_{\mathrm{p}} \rho_{\mathrm{p}} \varepsilon_{\mathrm{s}}^{\kappa-1}}{\delta^{\kappa-1}}+\kappa\left(\rho^{\prime}-1\right)-\rho^{\prime}}{\varepsilon_{\mathrm{s}}^{\kappa-1}\left\{\lambda_{\mathrm{p}}\left[\kappa \rho_{\mathrm{p}}-(\kappa-1)\left(1+\rho_{\mathrm{p}} \ln \rho_{\mathrm{T}}\right)\right]-1\right\}}
$$




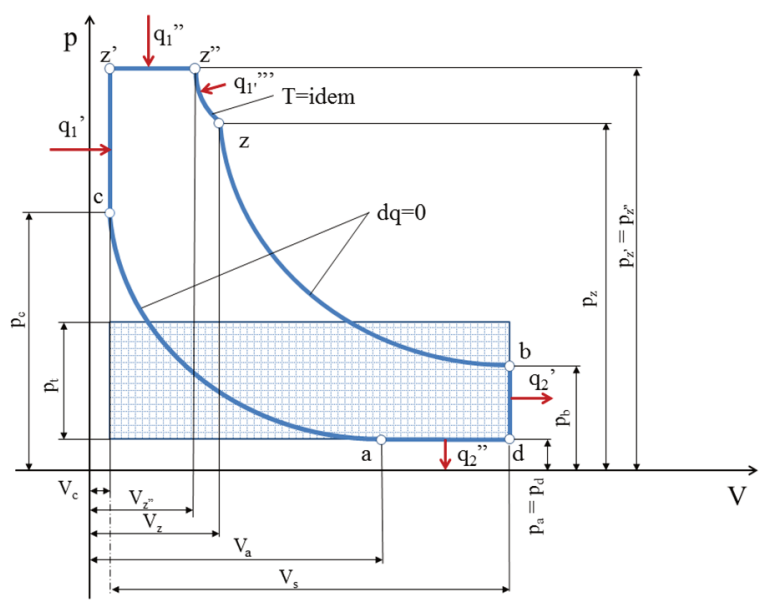

Fig. 2. Generalized thermodynamic cycle of a four-stroke internal combustion engine [2]

If each of the values forming the formula for efficiency are included in the volume change function, it will be possible to use the relationship (2) to describe the changes caused by changes in the engine swept volume (3) [19].

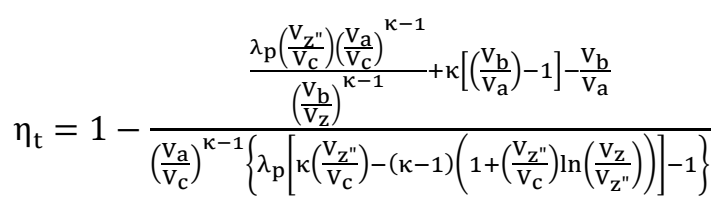

Components $\lambda_{\mathrm{p}}, \mathrm{V}_{\mathrm{a}}, \mathrm{V}_{\mathrm{z}}, \mathrm{V}_{\mathrm{z}}$,,$\kappa$ are resulting from the properties of the fuel used and the logistics of the combustion process, while $\mathrm{V}_{\mathrm{b}}$ and $\mathrm{V}_{\mathrm{c}}$ are constructional parameters of the combustion engine related to the combustion space and are therefore related to the operation within the rightsizing idea.

When assessing the effectiveness of using the rightsizing idea, three cases can be considered:

1. $\mathrm{V}_{\mathrm{sd}} \neq \mathrm{V}_{\mathrm{s}} ; \quad \mathrm{V}_{\mathrm{cd}}=\mathrm{V}_{\mathrm{c}} ; \quad \varepsilon_{\mathrm{d}} \neq \varepsilon$

2. $\mathrm{V}_{\mathrm{sd}} \neq \mathrm{V}_{\mathrm{s}} ; \quad \mathrm{V}_{\mathrm{cd}} \neq \mathrm{V}_{\mathrm{c}} ; \quad \varepsilon_{\mathrm{d}} \neq \varepsilon$

3. $\mathrm{V}_{\mathrm{sd}} \neq \mathrm{V}_{\mathrm{s}} ; \quad \mathrm{V}_{\mathrm{cd}} \neq \mathrm{V}_{\mathrm{c}} ; \quad \varepsilon_{\mathrm{d}}=\varepsilon$

In the first case, along with the change of the engine volume $\mathrm{V}_{\mathrm{s}}$ to $\mathrm{V}_{\mathrm{sd}}$ (index " $\mathrm{d}$ " informs about the change in volume) and while maintaining the volume of compression space $\left(\mathrm{V}_{\mathrm{c}}=\mathrm{V}_{\mathrm{cd}}\right)$ will change the compression ratio ( $\varepsilon$ to $\left.\varepsilon_{\mathrm{d}}\right)$.

In the second case, the analysis of changes caused by rightsizing is possible when either the volume of the compression space $\left(\mathrm{V}_{\mathrm{cd}}\right)$ or the geometric compression ratio $\left(\varepsilon_{\mathrm{d}}\right)$ will be a known input value.

In engineering practice, the known input value is the compression ratio, the value of which defines the correctness of self-ignition in the diesel engine and in the case of spark-ignition engines, it allows combustion of the working medium without knocking. In general, this means that the theoretical efficiency of the work cycle will be independent of the rate of changes in the volume of $\mathrm{W}_{\mathrm{d}}$, i.e. independent of the coefficients A and B.

The third case determines the change in the engine's swept volume $\left(\mathrm{V}_{\mathrm{s}}\right.$ to $\left.\mathrm{V}_{\mathrm{sd}}\right)$, which will be accompanied by the change of the compression space volume $\left(\mathrm{V}_{\mathrm{c}}\right.$ to $\left.\mathrm{V}_{\mathrm{cd}}\right)$ while maintaining the geometric degree of compression $(\varepsilon=$ $\left.\varepsilon_{\mathrm{d}}\right)$. This case was decided to consider in detail taking into account possible changes in the $\mathrm{A}$ and $\mathrm{B}$ coefficients described in Table 1.

Formula (3) describing the theoretical efficiency of the combustion engine cycle after rightsizing, in the case under consideration takes the form (4) [19]:

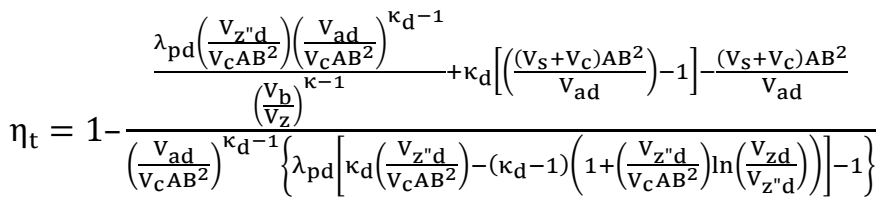

In the research methodology, successive values of pairs of coefficients A and B from table 1 are introduced, calculating changes in the thermodynamic efficiency of the work cycle. Other data was taken from the research on the 1.4 TSI engine, which is one of the links in the rightsizing engine chain of the Volkswagen brand.

\section{Evaluation of work cycle efficiency with variable volume of compression space for maintaining the geometric degree of compression}

The theoretical and experimental data from the tests of the VW 1.4 TSI combustion engine carried out in the Department of Automotive Engineering at the Wroclaw University of Science and Technology were used to assess the presented research problem. The tested 1.4 TSI engine is a smaller version of the 1.8 FSI one, which means the value of the change in the displacement volume $\mathrm{W}_{\mathrm{d}}=0.22-$ Figures 3 and 4.

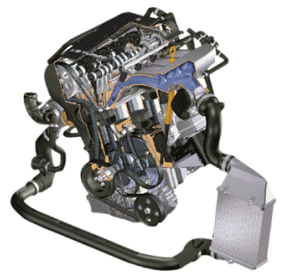

$1.8 \mathrm{~T}$ (years 1995-2008) AMB (125 kW; $225 \mathrm{Nm})$ CFMA $(110 \mathrm{~kW} ; 220 \mathrm{Nm})$

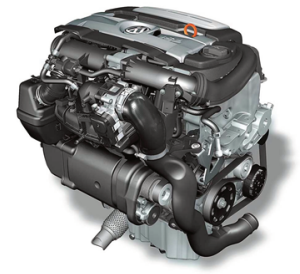

1.4 TSI (years 2005-...) CAVC $(125 \mathrm{~kW} ; 240 \mathrm{Nm})$ CAVB (103 kW; $220 \mathrm{Nm})$
Fig. 3. VW 1.8 and $1.4 \mathrm{dm}^{3}$ engines constituting the rightsizing chain [21]

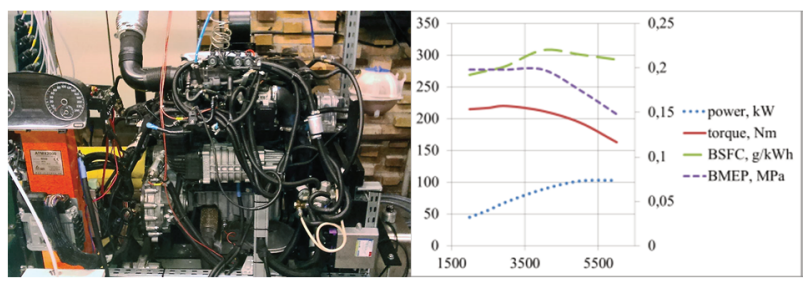

Fig. 4. VW $1.4 \mathrm{dm}^{3}$ engine on the test bench and its performance

Four different values (based on Table 1) of coefficients $\mathrm{A}$ and $\mathrm{B}$ were adopted for the study to obtain the same value of $\mathrm{W}_{\mathrm{d}}=0.22$. The remaining data filling the form of equation No. 4 was obtained from the mentioned laboratory tests. In this way, it was possible to estimate the efficiency value for the assessment of the impact of rightsizing when changing the compression space, while maintaining the geometric degree of compression - Table 2. 
Table 2. Efficiency values of the generalized motor cycle for the $\mathrm{W}_{\mathrm{d}}$ ratio $=0.22$ at variable values of piston stroke changes (factor A) and cylinder diameter (factor B)

\begin{tabular}{|c|c|c|c|}
\hline $\mathrm{A}$ & $\mathrm{B}$ & $\mathrm{W}_{\mathrm{d}}$ & $\eta_{\mathrm{t}}$ \\
\hline 1.08 & 0.85 & 0.220 & 0,502 \\
\hline 0.96 & 0.90 & 0,222 & 0,500 \\
\hline 0.86 & 0.95 & 0,224 & 0,499 \\
\hline 0.78 & 1.00 & 0,220 & 0,502 \\
\hline
\end{tabular}

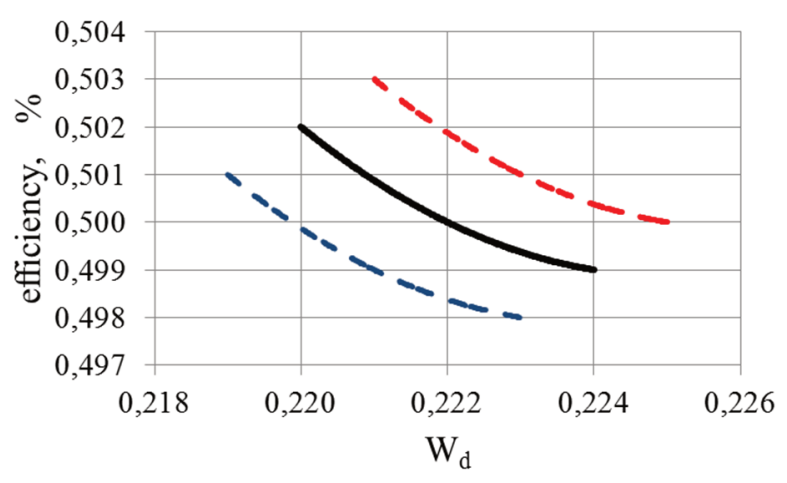

Fig. 5. Determination of significance of efficiency changes

The diagram - Fig. 5. presents changes in the average efficiency of the engine (center line) within the range of permissible deviations (bar lines) indicating the lack of significance of changes. For the case studied, the obtained results together with the evaluation of deviations of their value and thus the lack of statistical significance, indicate the invariance of the generalized cycle of operation of the internal combustion engine for different coefficients of change of parameters A and B shaping the size of geometrical changes of stroke volume while maintaining the index of changes in the displacement volume.

\section{Summary}

The work discusses the issue of the change in the displacement volume of an internal combustion engine, occurring in the generally realized development trend of rightsizing. The research problem was defined which was the assessment of the impact of different geometric changes in piston stroke and cylinder diameter while maintaining the same value of the index of changes in the displacement volume on the efficiency of the engine's work cycle. The data for the analysis was obtained from laboratory tests and using own software ensuring multiple estimation of indirect values defining the efficiency of the engine.

Assessing the case of the implementation of the rightsizing idea, in which the compression space was changed, while maintaining the geometric degree of compression, the results showed the invariance of the efficiency of the combustion engine cycle independently of the factors A and B, which determine the geometric changes in the swept volume of the engine. The results obtained should be interpreted so that the magnitude of changes in the efficiency of the work cycle depends on the global value of the volume change and not on its partial values.

\section{Nomenclature}

A coefficient of change of piston stroke

B coefficient of change of cylinder diameter

D cylinder diameter - input state

$\mathrm{D}_{\mathrm{d}} \quad$ cylinder diameter in the downsized engine

$\mathrm{S} \quad$ stroke of the piston - input state

$\mathrm{S}_{\mathrm{d}} \quad$ stroke of the piston in the downsized engine

$\mathrm{W}_{\mathrm{d}}$ downsizing index

$\delta \quad$ degree of another expansion process

$\varepsilon \quad$ geometric compression ratio

$\varepsilon_{\mathrm{s}} \quad$ effective compression ratio $\eta_{t} \quad$ theoretical efficiency of the work cycle

$\kappa \quad$ isentropic exponent

$\lambda_{\mathrm{p}}$ degree of pressure increase during isochoric heat transfer

$\rho^{\prime} \quad$ degree of pre-compression when heat is drained at constant pressure

$\rho_{\mathrm{p}} \quad$ degree of expansion during isobaric heat transfer

$\rho_{\mathrm{T}} \quad$ degree of expansion during isothermal heat transfer

\section{Bibliography}

[1] AMBROZIK, A. Wybrane zagadnienia procesów cieplnych w tłokowych silnikach spalinowych. Wydawnictwo Politechniki Świętokrzyskiej. Kielce 2003.

[2] AMBROZIK, A. Analiza cykli pracy czterosuwowych silników spalinowych. Wydawnictwo Politechniki Świętokrzyskiej. Kielce 2010

[3] AMBROZIK, A., DANILCZYK, W., KRUCZYŃSKI, S.W. Simulation of on indicato diagram of a diesel engine. Polish Academy of Sciences Branch in Lublin, Commission of Motorization and Energetics in Agriculture. 2003, Vol. III, 1217.

[4] BRZEŻAŃSKI, M., ŚLIWIŃSKI, K. Downsizing nowy kierunek rozwoju silników samochodowych. Silniki Spalinowe. 2004, 119(2), 3-11.

[5] FRASER, A.D.J. How low can we go? Challenges and opportunities of engine downsizing to reduce $\mathrm{CO}_{2}$ emis- sions. Seminar Proceedings IMechE. London, 9 February 2011, 1-9.

[6] FRASER, N., BASSETT, M. Extreme engine downsizing with a single turbochanger $-100 \mathrm{~kW} / \mathrm{l}$ and 30 bar BMEP. Seminar Proceedings IMechE. London, February 2011, 3145.

[7] GNUTEK, Z., NEMŚ, A., POMORSKI, M. Badania niestechiometrycznego spalania mieszanek wzbogaconych w tlen w silnikach cieplnych o zapłonie iskrowym. Materiały XIV Sympozjum Wymiany Ciepła i Masy. Międzyzdroje, 2010, Wydawnictwo Uczelniane Zachodniopomorskiego Uniwersytetu Technologicznego. Szczecin 2010, 217-224.

[8] GNUTEK, Z., KOLASIŃSKI, P.K. Application of volumetric machines in micro steam power plants. Archiwum Energetyki. 2010, 40(1/2), 63-74. 
[9] HEYWOOD, J.B., Internal Combustion Engine Fundamentals, McGraw HiU International Editions. 1989.

[10] JENTEGES, M., VAN DER WEEM, D. et al. Optimized activation of a downsizing concept with electrical boost. MTZ. 2006, 67(4).

[11] KEMPER, H., BAUMGARTEN, H., HEBERMANN, K. et al. On the road towards consequent downsizing. MTZ Worldwide. 2003, 54(5), 16-18.

[12] KING, J. Application of synergistic technologies to achive high levels of gasoline engine downsizing. Seminar Proceedings IMechE. London, 9 February 2011, 59-72.

[13] LUFT, S. Podstawy budowy silników. WKE. Warszawa 2006.

[14] PIELECHA, I., CIEŚLIK, W., BOROWSKI, P. et al. Reduction of the number of cylinders in internal combustion engines - contemporary trends in downsizing. Combustion Engines. 2014, 159(4), 12-25.

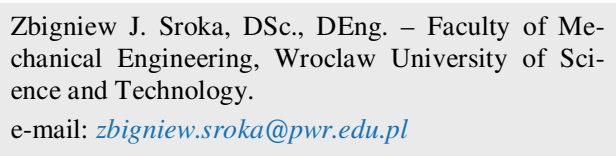

e-mail: zbigniew.sroka@pwr.edu.pl

[15] PISCHINGER, S. Verbrennungskraftmaschinen I. Aachen: RWTH. Aachen 2011.

[16] POSTRZEDNIK, A., ŻMUDKA, Z. Termodynamiczne oraz ekologiczne uwarunkowania eksploatacji tłokowych silników spalinowych. Politechnika Śląska. Gliwice 2007.

[17] RYCHTER, T.J., TEODORCZYK, A. Teoria silników tłokowych. WKE. Warszawa 2006.

[18] SROKA, Z.J., Some aspects of thermal load and operating indexes after downsizing for internal combustion engine. Journal of Thermal Analysis and Calorimetry. 2012, 110(1), 51-58.

[19] SROKA, Z.J. Wybrane zagadnienia teorii tłokowych silników spalinowych w aspekcie zmian objętości skokowej. Oficyna Wydawnicza Politechniki Wrocławskiej. Wrocław 2013.

[20] http://www.ukimediaevents.com/engineoftheyear/

[21] http://www.auto-swiat.pl

Maciej K. Dworaczyński, MSc. - Faculty of Mechanical Engineering, Wroclaw University of Science and Technology.

e-mail: maciej.dworaczynski@pwr.edu.pl 